\title{
Niğde İlindeki Çiğ Koyun, Keçi ve İnek Sütlerinde Aflatoksin $\mathbf{M}_{1}$ Düzeyleri
}

\author{
Fulden KARADAL ${ }^{1 *}$,Nurhan ERTAS ONMAZ ${ }^{2}$, Harun HIZLISOY ${ }^{3}$, Yeliz YILDIRIM², \\ Serhat AL $^{2}$, Zafer GONULALAN ${ }^{2}$ \\ ${ }^{1}$ Department of Food Processing, Bor Vocational School, Nigde Omer Halisdemir University, Nigde, Turkey \\ ${ }^{2}$ Department of Food Hygiene and Technology, Faculty of Veterinary Medicine, Erciyes University, Kayseri, Turkey \\ ${ }^{3}$ Department of Veterinary Public Health, Faculty of Veterinary Medicine, Erciyes University, Kayseri, Turkey \\ *Corresponding author e-mail: fkaradal@ohu.edu.tr
}

\begin{abstract}
ÖZ
$\mathrm{Bu}$ çalşşmada, Niğde ilinde tüketime sunulan çiğ inek, koyun ve keçi sütlerinde aflatoksin $\mathrm{M}_{1}\left(\mathrm{AFM}_{1}\right)$ varlı̆̆ının araştırılması, yasal düzenlemeler dikkate alınarak halk sağlığı yönünden tehlike oluşturup oluşturmadığının belirlenmesi ve sütlerdeki toksin içeriklerinin karșılaștırlması amaçlandı. Çalışmada, 90 çiğ süt örneği toplanarak ELISA tekniği ile analiz edildi. İncelenen tüm süt örneklerinin $\mathrm{AFM}_{1}$ ile kontamine olduğu koyun ve keçi sütlerindeki $\mathrm{AFM}_{1}$ düzeyinin yasal limitlerin altında, çiğ inek sütü örneklerinin 3'ünde (\%10) ise bu limitlerin üzerinde (50 ng/L) olduğu belirlendi. Ayrıca farklı hayvan türlerinin sütlerindeki $\mathrm{AFM}_{1}$ düzeyleri arasında istatistiksel olarak anlamlı farklılıklar gözlemlendi $(\mathrm{p}<0.05)$. Sonuç olarak, Niğde'de koyun ve keçi sütü tüketimi ile $\mathrm{AFM}_{1}$ 'e maruz kalma potansiyelinin inek sütü tüketimine oranla daha düşük olduğu belirlendi. Bununla birlikte inek sütlerinde yasal limitlerin üzerinde tespit edilen $\mathrm{AFM}_{1}$ varllğının halk sağlığı bakımından önemli olduğu ve bu nedenle sütlerin sistematik olarak kontrol edilmesi gerektiği sonucuna varıldı.
\end{abstract}

Anahtar Kelimeler: Aflatoksin $\mathrm{M}_{1}$, koyun sütü, keçi sütü, inek sütü, halk sağllğı.

\section{Aflatoxin $M_{1}$ Levels In Raw Sheep, Goat And Cow Milks In Niğde Province}

\begin{abstract}
This study aimed to investigate the presence of aflatoxin $\mathrm{M}_{1}\left(\mathrm{AFM}_{1}\right)$ in raw cow, sheep and goat milk consumed in Niğde and to evaluate whether they pose a risk for public health regarding legal limits and to compare the $\mathrm{AFM}_{1}$ levels in milk of different species. In the study, 90 raw milk samples were collected and analysed by ELISA tecnique. All of the milk samples were found to be contaminated with $\mathrm{AFM}_{1}$. On the other hand $\mathrm{AFM}_{1}$ contents of all sheep and goat milk samples were below the legal limits, while 3 of the raw cow milk samples $(10 \%)$ exceeded the limits of concern $(50 \mathrm{ng} / \mathrm{L})$. In addition, statistically significant differences were observed between $\mathrm{AFM}_{1}$ levels in milk of different species $(\mathrm{p}<0.05)$. In conclusion, $\mathrm{AFM}_{1}$ exposure risk in case of sheep and goat milk consumption is found to be lower than cow milk consumption in Niğde. However, presence of $\mathrm{AFM}_{1}$ in cow milk samples should be considered as a public health jeopardy, therefore milks should be systematically monitored.
\end{abstract}

Keywords: Aflatoxin $\mathrm{M}_{1}$, cow milk, goat milk, sheep milk, public health. 


\section{GİRIŞ̧}

Süt içerdiği protein, lipit, makro ve mikro elementler gibi temel besin maddeleri nedeniyle, özellikle gelişme çağındaki bireylerin yeterli ve dengeli beslenmesinde büyük önem taşımaktadır. Bununla birlikte, süt ve süt ürünlerinde bulunabilen aflatoksin $\mathrm{M}_{1} \quad\left(\mathrm{AFM}_{1}\right)$, bu tür ürünleri yüksek miktarda tüketen bireylerde sağlıkla ilgili olumsuz etkilere neden olabilmektedir. Aspergillus cinsindeki mikotoksijenik fungiler tarafindan üretilen aflatoksinler, farklı gida ve yem maddelerinde en çok araştırılan bulaşanlar grubudur (Creppy, 2002; Duarte ve ark. 2013). Yaklaşık 18 aflatoksin tespit edilmiștir. Bunların arasında Aflatoksin $\mathrm{B}_{1} \quad\left(\mathrm{AFB}_{1}\right)$, DNA hasarina, gen mutasyonuna, kromozom anomalilerine ve hücre transformasyonuna neden olan ve I. sinif insan kanserojeni olarak tanımlanan, toksik, mutajen ve teratojen bir bileşiktir (Anonim, 2017a). Karsinojenik gücü $\mathrm{AFB}_{1}$ 'den 10 kat daha düșük olan ve $\mathrm{AFB}_{1}$ 'in süt veren hayvanların karaciğerinde monohidroksile edilmiș türevi olan Aflatoksin $\mathrm{M}_{1}$ $\left(\mathrm{AFM}_{1}\right)$, Uluslararası Kanser Araştırmaları Ajansı (IARC - International Agency for Research on Cancer) tarafindan 2B sinifi kanserojen madde olarak kategorize edilmiştir (Anonim, 2017a).

$\mathrm{AFM}_{1}$ hayvanın vücudundan süt, idrar ve dışkı ile atılmaktadır. Sütteki $\mathrm{AFM}_{1}$ düzeyi, süt veren hayvanların yemlerle aldığ1 $\mathrm{AFB}_{1}$ oranına bağlı olarak değișmektedir. $\mathrm{AFM}_{1}$, kontamine olmuș yemlerin tüketilmesinden 2-3 gün sonra sütte ortaya çıkmakta ve sonraki 2-3 gün boyunca süt ile birlikte at1limı devam etmektedir (Murphy ve ark. 2006; Prandini ve ark., 2009; Sidhu ve ark. 2009). Toksinin pastörizasyon ve UHT (Ultra High Temperature) sterilizasyon gibi 1 sıl işlemlerde inaktive olmamas1 nedeniyle $\mathrm{AFM}_{1}$ sadece sütlerde değil, aynı zamanda yoğurt, peynir, tereyağı, krema, dondurma ve sütlü tatllar gibi süt ürünlerinde de bulunabilmektedir (Ertaş ve ark. 2011; Hassan ve Kassaify 2014).

Genotoksik, teratojenik ve insanlar için immünosüpresif olduğu bildirilen $\mathrm{AFM}_{1}$, üretim proseslerinde veya 1s1 ișlemlerinde yok olmadığından, bu metabolitin Avrupa Birliği (AB) tarafindan belirlenen maksimum kalintı seviyelerine göre, çiğ süt ve süt ürünlerinin en etkin kontrolünü sağlamak büyük önem taşımaktadır. (Creppy, 2002). $\mathrm{AFM}_{1}$, Codex Alimentarius, EU (European Union) ve Türk Gıda Kodeksi'nde (TGK) sütlerdeki maksimum $\mathrm{AFM}_{1}$ kalıntı oran1 $50 \mathrm{ng} / \mathrm{L}$ olarak belirlenmiștir (Anonim, 2006; Anonim, 2011; Codex, 2015).
Bu çalşmada, Niğde yöresinde tüketime sunulan inek, koyun ve keçi sütlerindeki $\mathrm{AFM}_{1}$ miktarı ve bu sütlerin tüketilmesinin oluşturduğu risklerin belirlenmesi amaçlanmıştır.

\section{MATERYAL ve METOT}

\section{Numuneler}

Bu çalışmada, Niğde ilindeki süt işletmelerinden, Haziran - Ağustos 2017 tarihleri arasında süt toplama merkezlerinden alınan 90 adet çiğ süt örneği (30 inek, 30 koyun, 30 keçi sütü) materyal olarak kullanıldı. Steril numune kaplarına 200'er mL olarak alınan süt örnekleri soğuk zincir altında laboratuvara getirilerek analiz edildi.

\section{Yöntem}

Çalışmada toplanan süt örneklerinde $\mathrm{AFM}_{1}$ seviyesi ELISA yöntemi ve ticari kit (Helica, Catalog No: 961AFLM01M-96, USA) ile belirlendi.

\section{Süt Numunelerinden AFM $_{1}$ Ekstraksiyonu}

$\mathrm{AFM}_{1}$ ekstraksiyonu için oda 1sısına getirilen süt örnekleri $2 \mathrm{~mL}$ 'lik eppendorf tüplerine aktarıldı ve 2000 g'de $5 \mathrm{dk}$ santrifüj edildi. Santrifüj süresi sonunda tüpün üst katmanında oluşan krema tabakası atıldı ve tüpün altında kalan kısımdan 100 $\mu \mathrm{L}$ alınarak ELISA testinde kullanıldı.

\section{ELISA Testi}

Standartlar ve örnekler için yeterli sayıda mikrotiter kuyucuk pleyte yerleştirildi. Standart solüsyonlarından ve hazırlanmış örneklerden 200'er $\mu \mathrm{L}$ alınarak kuyucuklara ilave edildi ve oda isisinda karanlık ortamda 2 saat inkübe edildi. İnkübasyon sonunda mikrotiter kuyucuklar, $\% 0,05$ 'lik Tween 20 içeren PBS (Phosphate Buffered Saline) ile ELISA otomatik strip yıkayıcıda (ELX 50, Bio-Tek Instruments, ABD) 3 kez yıkand. Her bir kuyucuğa 100 'er $\mu \mathrm{L}$ enzim konjugat ilave edilerek oda 1sisinda karanlık ortamda 15 dakika tekrar inkübasyona bırakıldı. İnkübasyon sonunda mikrotiter kuyucuklar ELISA otomatik strip yıkayıcıda 3 kez tekrar y1kandiktan sonra her bir kuyucuğa $100 \mu \mathrm{L}$ substrat ilave edildi ve iyice karıştırilarak oda 1sısında ve karanlık ortamda 15 dakika inkübe edildi. İnkübasyon sonunda her bir kuyucuğa 100 $\mu \mathrm{L}$ stop solüsyonu koyularak kuyucuklardaki reaksiyonun durması sağlandı. Pleyt, elle hafif şiddette vurmak suretiyle iyice karıştırıldı. ELISA otomatik okuyucuda (Thermo, Finland) $450 \mathrm{~nm}$ dalga boyunda okutuldu ve absorbanslar kaydedildi. 


\section{Sonuçların Değerlendirilmesi}

ELISA testi sonuçlarının değerlendirilmesinde; standartlar ve örnekler için bulunan absorbans değerlerinin ortalama değerleri, birinci standartın $(0$ ppt standardı) absorbans değerine bölündü ve 100 ile çarpıldı. Böylece 0 standardı \% 100'e eşit hale getirildi ve absorbans değerleri yüzde olarak bulundu. Standartlar için hesaplanan değerler, semilogaritmik grafik kağıdı üzerine ng/L (ppt) cinsinden $\mathrm{AFM}_{1}$ konsantrasyonuna karşı koordinatlar sistemine girildi. Her örneğin $\mathrm{AFM}_{1}$ konsantrasyonu eğri üzerinden $\mathrm{ng} / \mathrm{L}$ cinsinden okundu.

\section{İstatistiksel Yöntem}

Çalışmada, incelenen 3 gruba ait (Grup 1: Çiğ inek sütü, Grup 2: Çiğ koyun sütü, Grup 3: Çiğ keçi sütü) örnekler arasında $\mathrm{AFM}_{1}$ varllğı açısından istatistiksel bir farklılık olup olmadığ1 tek yönlü varyans analizi (One Way Anova) ile test edildi. Tek yönlü varyansa analizi sonucunda gruplar arasındaki farklı1ıkların belirlenmesinde çoklu karşılaştırma testlerinden Tukey testi kullanılmıştır Çalışmada uygulanan istatistiksel yöntemler SPSS 20.0 paket programı yardımıyla yapıldı.

\section{BULGULAR}

Çalısma kapsamında, analiz edilen toplam 90 süt örneğinin tamamında $0,33 \mathrm{ng} / \mathrm{L}-\quad 88,77 \mathrm{ng} / \mathrm{L}$ aralığında $\mathrm{AFM}_{1}$ tespit edildi. Analiz edilen süt örneklerinde $\mathrm{AFM}_{1}$ düzeylerinin belirlenmesi amac1 ile kullanılan standartların absorbans değerleri Tablo 1'de ve kalibrasyon eğrisi ise Şekil 1'de gösterildi.

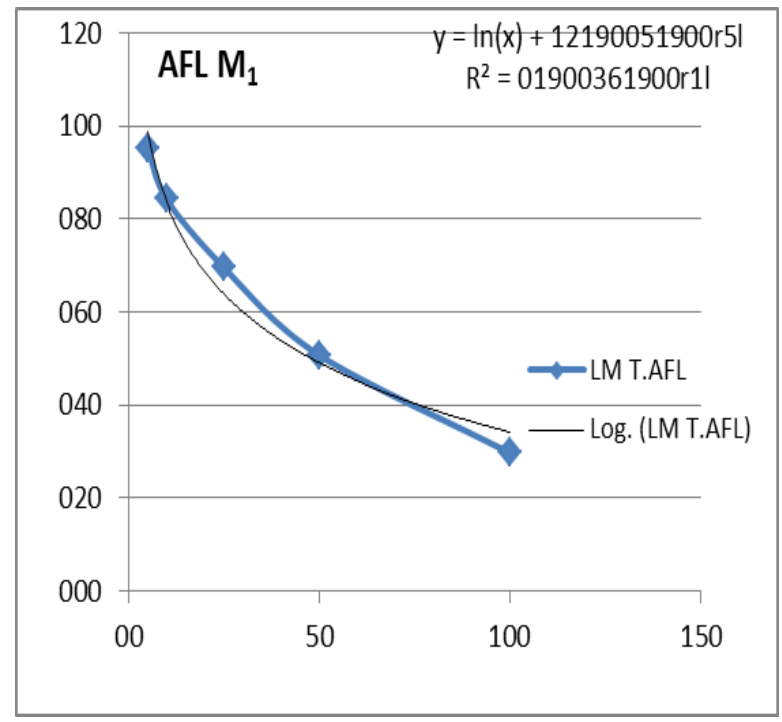

Şekil 1. $\mathrm{AFM}_{1}$ analiz kalibrasyon eğrisi

Figure 1. $\mathrm{AFM}_{1}$ analysis calibration curve

Tablo 1. $\mathrm{AFM}_{1}$ analizinde kullanılan standartların absorbans değerlerine göre elde edilen referans aralıkları

Table 1. Reference ranges obtained from the absorbance values of standards used in $\mathrm{AFM}_{1}$ analysis

\begin{tabular}{ccc}
\hline Standart & Konsantrasyonlarl (ng/L) & Ortalama Absorbans $\pm \%$ Standart Hata $(\mathrm{Sx})$ \\
\hline 1 & 0 & $1.1625 \pm 0.009$ \\
2 & 5 & $1.1076 \pm 0.008$ \\
3 & 10 & $0.98 \pm 0.009$ \\
4 & 25 & $0.8093 \pm 1.00$ \\
5 & 50 & $0.5898 \pm 0.009$ \\
6 & 100 & $0.3453 \pm 0.006$ \\
\hline
\end{tabular}

Çalşsmada incelenen inek, koyun ve keçi, sütlerinin sirasiyla $1,84-88,77 \mathrm{ng} / \mathrm{L}, 1,82-7,83 \mathrm{ng} / \mathrm{L}$ ve $0,33-$ $11,79 \mathrm{ng} / \mathrm{L}$ aralıklarında $\mathrm{AFM}_{1}$ içerdiği belirlendi. Analiz edilen inek, koyun ve keçi sütü örneklerine ait $\mathrm{AFM}_{1}$ dağılımları Tablo 2'de özetlendi.

Çalısma süresince analiz edilen çiğ inek sütü örneklerinin 3'ünde (\%10) Türk Gıda Kodeksinin süt ürünleri için belirlemiş olduğu maksimum limit olan $50 \mathrm{ng} / \mathrm{L}$ 'in üzerinde $\mathrm{AFM}_{1}$ tespit edilirken, koyun ve keçi sütü örneklerinin tamamının $\mathrm{AFM}_{1}$ seviyesi yasal limitlerin altında bulundu. Analiz edilen inek sütlerinde tespit edilen $\mathrm{AFM}_{1}$ seviyeleri ile koyun ve keçi sütlerindeki $\mathrm{AFM}_{1}$ miktarı arasında belirgin istatistiksel bir farkllik olduğu $(\mathrm{p}<0.05)$; koyun ve keçi sütü $\mathrm{AFM}_{1}$ seviyeleri arasında ise istatistiksel açıdan farklılık olmadığ 1 ortaya kondu $(\mathrm{p}>0,05)$ (Tablo 2$)$. 
Tablo 2. Çalışmada analiz edilen örneklere ait $\mathrm{AFM}_{1}$ düzeyleri

Table 2. AFM 1 levels in the samples analyzed in this study

\begin{tabular}{|c|c|c|c|c|c|c|c|c|}
\hline \multirow{2}{*}{$\begin{array}{l}\text { Analiz Edilen } \\
\text { Örnek }\end{array}$} & \multirow{2}{*}{$\begin{array}{l}\text { Örnek } \\
\text { Say1s1 }\end{array}$} & \multicolumn{3}{|c|}{ Örneklerdeki $\mathrm{AFM}_{1}$ dağılımı /(\%) } & \multicolumn{4}{|c|}{$\mathrm{AFM}_{1}$ Konsantrasyonu (ng/L) } \\
\hline & & $<25 \mathrm{ng} / \mathrm{L}$ & $25-50 \mathrm{ng} / \mathrm{L}$ & $>50 \mathrm{ng} / \mathrm{L}$ & $\bar{X} \pm \mathrm{S} \bar{X}$ & Min & Max & $\mathrm{F}$ \\
\hline Çiğ inek sütü & $30 \mathrm{a}$ & $26(\% 87)$ & $1(\% 3)$ & $3(\% 10)$ & $15.88^{\mathrm{a}} \pm 4.4$ & 1.84 & 88.77 & 7 \\
\hline Çiğ koyun sütü & 3 & $30(\% 100)$ & - & - & $3.91 \mathrm{~b} \pm 0.25$ & 1.82 & 7.83 & 6 \\
\hline Çiğ keçi sütü & 30 & $30(\% 100)$ & - & - & $3.07 \mathrm{~b} \pm 0.42$ & 0.33 & 11.79 & 6 \\
\hline Toplam & 90 & $86(\% 96)$ & $1(\% 1)$ & $3(\% 3)$ & & & & \\
\hline
\end{tabular}

$\overline{\bar{X}} \pm s \bar{X}:$ Ortalama \pm standart hata

$\stackrel{a, b}{0}$ farklı harfler gruplar arasındaki farkın önemli olduğunu göstermektedir $(\mathrm{p}<0.05)$.

\section{TARTIŞMA}

Son yllarda, çiğ sütteki $\mathrm{AFM}_{1}$ kontaminasyonunun izlenmesi için ülkemizin Van, Burdur, Nevşehir, Bursa, Eskişehir, Ankara, Antalya, Kars, Kilis, Kayseri ve Afyon illerinden elde edilen süt örnekleri kullanılarak birçok çalışma yapılmıştır (Bakırc1, 2001; Akdemir ve Altıntaş, 2004; Kireçci ve ark. 2007; Özdemir, 2007; Ertaş ve ark. 2011; Kara ve İnce, 2014). Haziran-Ağustos aylarında süt toplama merkezlerinden temin edilen örneklerle gerçekleştirilen bu çalışmada AFM1 konsantrasyonu: İnek sütü örneklerinde analiz edilen örneklerin 3 'ü (\%10) yasal sinırların üzerinde olmak üzere 1,84-88,77 ng/L arasında; koyun sütü örneklerinde 1,82-7,83 ng/L arasında; keçi sütü örneklerinde 0,33-11,79 ng/L arasında tespit edildi. Değişik araştırmacılar tarafından çeşitli ülkelerde ve mevsimlerde yapılmış olan ve çiğ süt örneklerinde AFM1 düzeylerine ilişkin bazı çalışmalara ait sonuçlar Tablo 3'te özet halinde verilmiştir.

Çalışmada analiz edilen çiğ inek sütlerinde $\mathrm{AFM}_{1}$ yönünden Türkiye ve Avrupa Birliği limitlerini aşan örnek oranı (\%10), bazı araştırmacilar (Ertas ve ark., 2011; Kara ve İnce, 2014; Bilandzic ve ark. 2017) tarafindan saptanan değerlerden yüksek, bazıları (Akdemir ve Altıntaş 2004; Kireçci ve ark. 2007; Rahimi ve ark. 2010; Bilandzic ve ark. 2014) tarafindan tespit edilen değerlerden düşük, Roussi ve ark. (2002) tarafindan bulunan orana ise benzerdir (Tablo 3). Sonuçlar arasındaki farkliliklar özellikle örneklerin alındığı mevsim ve coğrafik koşullardaki farklılıkla (Tablo 3) ilişkili olabilir. Bilindiği gibi uygun olmayan koşullarda muhafaza edilen yemde üreyen küf mantarlarının meydana getirdiği $\mathrm{AFB}_{1}$, sütteki $\mathrm{AFM}_{1}$ 'in kaynağıdır. Buna bağl1 olarak $\mathrm{AFM}_{1}$ 'in sütteki seviyesinin yaz aylarında daha düşük olduğu, bunun sebebinin de yaz aylarında süt ineklerinin kontamine konsantre yemlerden çok taze otlarla beslenmesi olduğu belirtilmektedir (Roussi ve ark. 2002; Asi ve ark.
2012; Malissiova ve ark. 2013; Bilandzic ve ark. 2014a; Bahrami ve ark. 2016; Bilandzic ve ark. 2017). Bu çalışmada analiz edilen bazı inek sütlerinin $\mathrm{AFM}_{1}$ kontaminasyon düzeyi, örneklerin elde edildiği süt toplama merkezlerine gelen inek sütlerinin temin edildiği işletmelerde kontamine konsantre yemlerin kullanıldığını düşündürmektedir.

Analiz edilen koyun süt örneklerindeki $\mathrm{AFM}_{1}$ konstrasyonunun yapilan diğer araştırmalarda elde edilen sonuçlarla (Tablo 3) ile karşılaştırıldığında bazı araştırmacıların (Finoli ve Vecchio, 2003; Kaniou-Grigoriadou ve ark. 2005; Bilandzic ve ark. 2014b; Bilandzic ve ark. 2017) bulguları ile uyumlu olarak yasal sınırların altında olduğu belirlendi. Buna karşın, Roussi ve ark. (2002) ve Rahimi ve ark. (2010) ve Fallah ve ark. (2011) bu çalışma sonuçlarından farklı olarak sırasıyla, \%6.7, \%3.9 ve $\% 25$ 'inde $\mathrm{AFM}_{1}$ düzeylerinin yasal limitlerin üzerinde olduğunu rapor etmişlerdir. Ayrıca bu çalışmada incelenen keçi sütü örneklerinin $\mathrm{AFM}_{1}$ konsantrasyonlar1 da Roussi ve ark. (2002), Bilandzic ve ark. (2014b); Bilandzic ve ark. (2017)'nın yaptıkları çalışmaların sonuçlarıyla paralel bir şekilde ve yasal sınırların altında bulunmuştur. Buna karşılık diğer bazı araştırmacılar (Rahimi ve ark. 2010; Özdemir 2007) analiz ettikleri keçi sütlerinin yasal limitin üzerinde $\mathrm{AFM}_{1}$ içerdiğini bildirmişlerdir (Tablo 3). Araştırma sonuçlarındaki farklılıklar, örneklerin alındığı mevsime, kullanılan analiz yöntemlerine ve hayvanların beslenme şekillerine bağlanabilir. Yapılan çalışmalar sütlerdeki $\mathrm{AFM}_{1}$ düzeyinin, bölgenin mevsimsel, coğrafik ve iklim özelliklerine bağlı olarak süt veren hayvanların rasyonlarından ve laktasyon periyodundan etkilendiğini göstermektedir (Rahimi ve ark. 2010; Malissiova ve ark. 2013). 
Tablo 3. Çiğ süt örneklerinde $\mathrm{AFM}_{1}$ düzeylerine ilişkin bazı çalışma sonuçları

Table 3. Results of the some studies on $\mathrm{AFM}_{1}$ levels in raw milk samples

\begin{tabular}{|c|c|c|c|c|c|}
\hline Ülke & Ay & $\begin{array}{l}\text { Sütün } \\
\text { alındığ1 } \\
\text { hayvan } \\
\text { türü }\end{array}$ & $\begin{array}{l}\text { AFM }_{1} \\
\text { kontaminasyon } \\
\text { düzeyi }\end{array}$ & $\begin{array}{l}\text { Yasal limitlerin } \\
\text { üzerindeki } \\
\text { örnek oranı (\%) }\end{array}$ & Literatür \\
\hline Türkiye & Belirtilmemiş & İnek sütü & $10-817 \mathrm{ng} / \mathrm{L}$ & $\% 33.3$ & $\begin{array}{l}\text { Akdemir ve Altıntaş } \\
\text { (2004). }\end{array}$ \\
\hline Türkiye & $\begin{array}{l}\text { A ğustos- } \\
\text { Ocak }\end{array}$ & İnek sütü & $<8 \mathrm{ng} / \mathrm{L}$ & - & Kara ve İnce (2014). \\
\hline Türkiye & Aralık-Şubat & İnek sütü & $5-250 \mathrm{ng} / \mathrm{L}$ & $\% 90$ & Kireçci ve ark. (2007). \\
\hline Türkiye & Ocak-Mart & İnek sütü & $1-30 \mathrm{ng} / \mathrm{L}$ & - & Ertaş ve ark. (2011). \\
\hline Türkiye & Mart- Nisan & Keçi sütü & $5.16-116.78 \mathrm{ng} / \mathrm{L}$ & $\% 6.36$ & Özdemir (2007). \\
\hline İtalya & $\begin{array}{l}\text { Kasım- } \\
\text { Haziran }\end{array}$ & Koyun sütü & 4-23 ng/L & - & $\begin{array}{l}\text { Finoli ve Vecchio } \\
\text { (2003). }\end{array}$ \\
\hline Yunanistan & $\begin{array}{l}\text { Mart- } \\
\text { Haziran }\end{array}$ & Koyun sütü & $0-18.2 \mathrm{ng} / \mathrm{L}$ & - & $\begin{array}{l}\text { Kaniou-Grigoriadou } \\
\text { ve ark. (2005). }\end{array}$ \\
\hline Yunanistan & Aralık-Mayıs & $\begin{array}{l}\text { İnek sütü } \\
\text { Koyun sütü } \\
\text { Keçi sütü }\end{array}$ & $\begin{array}{l}<5->50 \mathrm{ng} / \mathrm{L} \\
<5->50 \mathrm{ng} / \mathrm{L} \\
<5-<20 \mathrm{ng} / \mathrm{L}\end{array}$ & $\begin{array}{c}\% 3.6 \\
\% 6.7 \\
-\end{array}$ & Roussi ve ark. (2002). \\
\hline Hirvatistan & $\begin{array}{l}\text { Temmuz- } \\
\text { Eylül }\end{array}$ & $\begin{array}{l}\text { İnek sütü } \\
\text { Koyun sütü } \\
\text { Keçi sütü } \\
\text { İnek sütü }\end{array}$ & $\begin{array}{l}<23.2->50 \mathrm{ng} / \mathrm{L} \\
<23.2-49.9 \mathrm{ng} / \mathrm{L} \\
<23.2-49.9 \mathrm{ng} / \mathrm{L} \\
0.93-71.1 \mathrm{ng} / \mathrm{L}\end{array}$ & $\begin{array}{c}\% 6.7 \\
- \\
- \\
\% 0.3\end{array}$ & $\begin{array}{l}\text { Bilandzic ve ark. } \\
\text { (2014b). }\end{array}$ \\
\hline Hirvatistan & Mart- Mayis & $\begin{array}{l}\text { Koyun sütü } \\
\text { Keçi sütü } \\
\text { İnek sütü }\end{array}$ & $\begin{array}{l}2.18-15.8 \mathrm{ng} / \mathrm{L} \\
2.67-13.8 \mathrm{ng} / \mathrm{L} \\
<5->50 \mathrm{ng} / \mathrm{L}\end{array}$ & $\begin{array}{c}- \\
- \\
\% 36\end{array}$ & $\begin{array}{l}\text { Bilandzic ve ark. } \\
\text { (2017). }\end{array}$ \\
\hline İran & $\begin{array}{l}\text { Kasim 2007- } \\
\text { Aralık } 2008\end{array}$ & $\begin{array}{l}\text { Koyun sütü } \\
\text { Keçi sütü }\end{array}$ & $\begin{array}{l}<5->50 \mathrm{ng} / \mathrm{L} \\
<5->50 \mathrm{ng} / \mathrm{L}\end{array}$ & $\begin{array}{l}\% 3.9 \\
\% 5.7\end{array}$ & Rahimi ve ark. (2010). \\
\hline
\end{tabular}

$\mathrm{Bu}$ araştırma sonuçlarına uygulanan istatistik çalışmasına göre, analiz edilen inek sütlerinde tespit edilen $\mathrm{AFM}_{1}$ seviyeleri ile koyun ve keçi sütlerindeki $\mathrm{AFM}_{1}$ miktarı arasında istatistiksel bir farkll11k olduğu $(\mathrm{p}<0.05)$; koyun ve keçi sütü $\mathrm{AFM}_{1}$ seviyeleri arasında ise istatistiksel açıdan farklilık olmadığ ortaya kondu ( $\mathrm{p}>0,05)$. Bahrami ve ark. 2016) İran'da yaptıkları çalışmada koyun- keçi ve koyun-inek sütleri arasında farklılık bulamadıklarını, ancak inek- keçi sütleri arasında farklıllk olduğunu belirtmişlerdir. Bu çalsşma ile uyumlu olarak keçi ve koyun sütlerinde $\mathrm{AFM}_{1}$ kontaminasyon seviyelerinin, inek sütüyle karşılaştırıldığında, Yunanistan, İtalya, Hirvatistan, Lübnan ve İran'da da düşük bulunduğu rapor edilmektedir (Roussi ve ark. 2002; Rahimi ve ark. 2010; Malissiova ve ark. 2013; Bilandzic ve ark. 2014b; Hassan ve Kassaify 2014; Viridis ve ark. 2014; Bilandzic ve ark. 2017). $\mathrm{Bu}$ durum, koyun ve keçilerin ineklere oranla daha fazla dış ortamda otlatılarak beslenmesi ile ilişkilendirilebilir (Molle ve ark. 2008). Niğde Valiliği ve Niğde Ömer Halisdemir Üniversitesi işbirliği ile hazırlanan Niğde İl Gelişme Planı'nda (NIGGEP) Niğde'deki koyun ve keçi sürülerinin çoğunlukla otlatmaya dayalı yetiştirildiği bildirilmektedir (Anonim, 2017b).

$\mathrm{Bu}$ çalş̧mada, $\mathrm{AFM}_{1}$ kontaminasyon düzeyi yasal sınırları aşan az sayıda örnek tespit edilmiş olsa da, $\mathrm{AFM}_{1}$ 'in toplum sağllğına olabilecek olası zararlarını önlemek için $\mathrm{AFM}_{1}$ 'in süt toplama merkezlerinde daha etkin bir şekilde izlenmesi gerektiği ortaya çıkmaktadır. Bu amaçla, süt üreticileri, tedarikçileri ve tüketicilerin aflatoksinlerin sağlığa zararları ve sütteki $\mathrm{AFM}_{1}$ tehlikesi konusunda düzenli olarak bilgilendirilmeleri, olası bir halk sağlı̆̆ riskinin önlenmesinde çözüm yolu olarak önem taşımaktadır.

\section{KAYNAKLAR}

Akdemir Ç, Altıntaş A. Ankara'da işlenen sütlerde aflatoksin-M1 varlığının ve düzeylerinin HPLC ile araştırılması. Ankara Üniv Vet Fak Derg. 2004; 51:175-179.

Anonim, 2006. European Commission. Commission regulation (EC) No 1881 of 19 December 2006, setting maximum levels for 
certain contaminants in foodstuffs. Off J Europ Union L364:5-24.

Anonim, 2011. TGK, Türk Gida Kodeksi Bulaşanlar Yönetmeliği (29.12.2011 Tarih ve 28157 (3. Mükerrer) Sayll RG).

Anonim, 2017a. International Agency for Research on Cancer (IARC). List of classifications. Erişim tarihi: 12.10. 2017. http://monographs.iarc.fr/ENG/Classificat ion/latest_classif.php

Anonim, 2017b Niğde İl Gelişme Planı (NİGEP). $\quad 06.02 .2017$ http://www.nigdetb.org.tr/Portals/

218/selection. pdf. http://www.ohu.edu.tr/haber/nigde-ilgelisme-plani-tanitim-toplantisi-yapildi/208. Erişim tarihi: 15.09.2017

Asi MR., Iqbal SZ, Ariño A, Hussain A. Effect of seasonal variations and lactation times on aflatoxin $\mathrm{M}_{1}$ contamination in milk of different species from Punjab, Pakistan. Food Contr. 2012; 25(1): 34-38.

Bahrami R. Shahbazi Y, Nikousefat Z. Aflatoxin $\mathrm{M}_{1}$ in milk and traditional dairy products from west part of Iran: occurrence and seasonal variation with an emphasis on risk assessment of human exposure. Food Contr. 2016; 62: 250- 256.

Bakirci I. A study on the occurrence of aflatoxin $\mathrm{M}_{1}$ in milk and milk products produced in Van province of Turkey. Food Control 2001; 12(1):47-51.

Bilandzic N, Bozic D, Dokic M, Sedak M, Solomun Kolanovi, B., Varenina, I., Tanković S, Cvetnićc Z. Seasonal effect on aflatoxin M1 contamination in raw and UHT milk from Croatia. Food Contr. 2014a; 40: 260-264.

Bilandzic N, Luburic BD, Dokic M, Sedak M, Kolanovi SB, Varenina I, Cvetnic $Z$. Assessment of aflatoxin M1 contamination in milk of four dairy species in Croatia. Food Contr. 2014b; 43:18-21.

Bilandzic N, Varenina I, Kolanovic SB, Luburic BD, Varga I, Zeljezic B, Cvetnic L, Benic M, Sanin Tankovic, Cvetnic Z. Occurrence of aflatoxin M1 in raw cow, goat and sheep milk during spring and autumn in Croatia during 2016. Toxin Rev. 2017; Early Online: $1-7$. DOI: 10.1080/15569543.2017.1306785

Codex Alimentarius. International Food Standards. General Standard for contaminants and toxins in food and feed. Codex Stan 193-1995. Amended in 2015.
Creppy EE. Update of survey, regulation and toxic effects of mycotoxins in Europe. Toxicol Lett.. 2002; 127: 19-28.

Duarte SC, Almeida AM, Teixeira AS, Pereira AL, Falcão AC, Pena A, Lino CM. Aflatoxin $\mathrm{M}_{1}$ in marketed milk in Portugal: Assessment of human and animal exposure, Food Contr. 2013; 30: 411-417.

Ertas N, Gonulalan Z, Yildirim Y, Karadal F. A survey of concentration of aflatoxin $\mathrm{M}_{1}$ in dairy products marketed in Turkey. Food Contr. 2011; 22(12): 1956-1959.

Fallah AA, Rahnama M Jafari T, Saei Dehkordi SS. Seasonal variation of aflatoxin $M_{1}$ contamination in industrial and traditional Iranian dairy products. Food Contr. 2011; 22: 1653-1656.

Finoli C, Vecchio A. Occurrence of aflatoxins in feedstuff, sheep milk and dairy products in western Sicily. Ital J Anim Sci. 2003; 2(3): 191-196.

Hassan HF, Kassaify Z. The risks associated with aflatoxins $M_{1}$ occurrence in Lebanese dairy products. Food Contr. 2014; 37: 68-72.

Kaniou-Grigoriadou I, Eleftheriadou A, Mouratidou T. Katikou P. Determination of aflatoxin $\mathrm{M}_{1}$ in ewe's milk samples and the produced curd and Feta cheese. Food Contr. 2005; 16: 257-261.

Kara R, Ince S. Aflatoxin $\mathrm{M}_{1}$ in buffalo and cow milk in Afyonkarahisar, Turkey. Food Addit Contam Part B 2014; 7(1): 7-10.

Kireçci E, Savaşçı M, Ayyıldız A. Sarıkamış’ta tüketilen süt ve peynir ürünlerinde aflatoksin M1 varlığının belirlenmesi. İnfeksiyon Derg. 2007;21(2):93- 96.

Malissiova E, Tsakalof A, Arvanitoyannis IS, Katsafliaka A, Katsioulis A, Tserkezou P, Koureasa M, Govarise A, Hadjichristodoulou C. Monitoring Aflatoxin $\mathrm{M}_{1}$ levels in ewe's and goat's milk in Thessaly, Greece; potential risk factors under organic and conventional production schemes. Food Contr. 2013; 34: 241-248.

Molle G, Decandia M, Cabiddu A, Landau SY, Cannas A. An update on the nutrition of dairy sheep grazing Mediterranean pastures. Small Ruminant Res. 2008; 77:93-112.

Murphy PA, Hendrich S, Landgren C, Bryant C. Food mycotoxins: an update. J Food Sci. 2006; 71: R51-R65.

Özdemir M. Determination of Aflatoxin $\mathrm{M}_{1}$ Levels in goat milk consumed in Kilis 
Province. Ankara Üniv Vet Fak Derg. 2007; 54: 99-103.

Prandini A, Tansini G, Sigolo S, Filippi L, Laporta M, Piva G. On the occurrence of aflatoxin $\mathrm{M}_{1}$ in milk and dairy products. Food Chem Toxicol. 2009; 47: 984-991.

Rahimi E, Bonyadian M, Rafei M, Kazemeini HR. Occurrence of aflatoxin $\mathrm{M}_{1}$ in raw milk of five dairy species in Ahvaz, Iran. Food Chem Toxicol. 2010; 48(1):129-131.

Roussi V, Govaris A, Varagouli A, Botsoglou NA. Occurrence of aflatoxin $M$ (1) raw and market milk commercialized in Greece. Food Addit Contam. 2002; 19(9):863-868.

Sidhu OP, Chandra H, Behl HM. Occurrence of aflatoxins in mahua (Madhuca indica Gmel.) seeds: synergistic effect of plant extracts on inhibition of Aspergillus flavus growth and aflatoxin production. Food Chem Toxicol. 2009; 47(4): 774-7.

Viridis S, Scarano C, Spanu V, Murittu G, Ibba I, de Santis E. A survey on Aflatoxin M1 content in sheep and goat milk produced in Sardinia Region, Italy (2005-2013). Ital. J Food Saf. 2014; 3: 206-209. 